\title{
Development, Democracy, and Post-Islamism in Indonesia
}

\author{
Azlan Tajuddin ${ }^{1}$ \\ ${ }^{1}$ Department of Sociology, La Roche College, Pittsburgh, PA, USA. \\ Correspondence: Azlan Tajuddin, La Roche College, 9000 Babcock Boulevard, Pittsburgh, PA 15237, USA.
}

Received: September 9, 2016

Accepted: September 28, 2016

Available online: October 14, 2016

doi:10.11114/ijsss.v4i11.1924

URL: http://dx.doi.org/10.11114/ijsss.v4i11.1924

\begin{abstract}
The democratization of Indonesia since the late 1990s has inspired an unprecedented atmosphere of openness and inclusion in the country. Accordingly, many political organizations including Islamic parties and movements have liberalized their organizational philosophies to accommodate a wider and more diverse range of issues and concerns. Several Islamist groups too, while maintaining their Islamic identity, have since transitioned toward secularizing their goals and objectives as a means to adapt to the changing political environment. Political analysts refer to this development as Post-Islamism. To understand Post-Islamism in Indonesia, this article analyzes the historical development of political Islam through the interplays between changing global-historical currents and local cultural-political conditions.
\end{abstract}

Keywords: Indonesia, political Islam, Post-Islamism, Islamism, democracy, culture

\section{Introduction}

Islam occupies a central place in the daily lives of many Indonesians. As a political force, it has asserted a significant presence in the country's electoral landscape. Various Islamic organizations, for example, have long argued for a greater and more prominent role of Islam in Indonesia's political infrastructure. The more aggressive among them-the Islamists - go a step further by propagating for the creation of a fully-functioning Islamic state. By so doing, Islamists have consistently provided the primary challenge to state power and authority in Indonesia. However, the new democracy in Indonesia since the ouster of the Suharto government has been accompanied by a paradigmatic shift among various Islamic organizations, Islamist parties included, toward an increasingly secular outlook. Understanding this transition requires analyzing the concepts of Islamism and Post-Islamism within the context of Indonesia's larger development discourse.

\section{Islamism and Post-Islamism}

Islamism refers to a political philosophy and movement that actively strives for the establishment of an Islamic social-political existence (Bayat, 2005). To Islamists, the Islamic state embodies the ideal political organization, in which the realms of religion and politics lie in a rather porous existence. As such, an Islamic state's constitutional framework is often proposed to incorporate laws and principles directly derived from religious texts and scriptures.

The origins of Islamism can be traced to the period of European colonialism in the Middle East and South Asia. A new generation of Muslim scholars emerged, troubled by the pervasive social and intellectual inertia affecting the Muslim ummah (community) (Ansari, 2009, pp. 250-252). They poignantly argued that the decline in Islamic technological advancement was symptomatic of the overall weakening of Islam as a social, political, and economic force. They attributed this to two major factors. First was the relegation of Islam to mere cultural practices, which allowed Muslim societies to easily succumb to westernization. Second was the complicity of the local ulama (traditional scholars) and traditional nobility in the colonial mission to de-institutionalize Islam (Tajuddin, 2012, pp.95-96). Both of these served to not only sustain European colonial hegemony (and along with it the privileges of the local elites) but also systemically impede Muslims from social, educational, and political changes.

In essence, Islamists began as reformists. They asserted that Muslims could only advance in the modern age by reverting to the true practices of Islam based on the principle of ta'muruna bil ma'ruf, watanhauna 'anil munkar (enjoining the good and forbidding the wrong) (The Quran, Al-Imran 3:110). This, they believed, would lead to the rediscovery of the social virtuousness and intellectualism that had once made the Muslim ummah a vibrant civilization (Lapidus, 1997; Dallal, 1993). Critical to achieving this was a modern Islamic education premised on the openness in 
scriptural interpretation and emphases on science. Throughout the turn of the twentieth century, notable figures such as Muhammad Abduh, Jamal din Al-Afghani, Hassan Al-Banna, and Abul Ala Maududi, advocated for a reform in Islamic education and practice through Islamic conceptual renewing (tajdid) and reviving (ihya).

Today's Islamists have retained much of the early reformist views but give greater focus on the political channels for their Islamization goals. They believe the administrative apparatus to be the most expedient vehicle in transmitting Islamist ideas as it helps prepare the legitimate framework needed for the realization of an Islamic political system (Bayat, 2013, p.4). Here, the structural process becomes critical in facilitating as well as optimizing the implementation of Islamic laws such as the Sharia (Islamic penal code). The various participation of Islamist parties in the political system of countries such as Algeria, Bangladesh, and Malaysia have shown to enhance these parties' respective ability in socially disseminating their doctrinal influences (Roy, 1998).

In contrast, there are also Islamist organizations that opt for insurgency as the only feasible means to establish an Islamic state. Here, the Islamic identity is often aligned with an oppressed ethnic group or social class. Such organizations include the secessionist Moro Islamic Liberation Front (Philippines) and rebel Groupe Islamique Armé (Algeria). These Islamists however, must be distinguished from transnational jihadi groups such as Al-Qaeda or ISIL (Islamic State of Iraq and the Levant), whose ideological justifications for violence and militancy are derived from their own accounts of apocalyptic crusades. Summarily, jihadis pursue a cause that is universal while most Islamist groups confine their political goals within a particular country.

In any case, the majority of Islamists do converge on a conservative and exclusive form of Islam that provides little space for differences in ideas and practices (Dagi, 2013, p.72). Their priorities, missions, and obligations are pivoted around God's commands on earth, and in this, Islamists have been steadfast in their struggle toward establishing a comprehensive Islamic legal and political order. Over the years however, an increasing number of Islamists have become more inclined toward change. Glimpses of this transition first appeared in Iran. The end of the war with Iraq and the death of Ayatollah Khomeini in the late 1980s were followed by efforts by a growing number of former Islamist intellectuals, civic leaders, and politicians to push ahead for a liberalization of the political system. This group believed in the blending of Islam with secular democracy as a more appropriate approach in adapting Iran to the realities of a modern world. The election of Mohammed Khatami as President in 1997 signaled the pioneering success of this movement. Although many of Khatami's proposals were blocked by the hardliners in the Supreme Council, this new wave of progressivism marked a fledgling movement in political Islam in both Iran and many parts of the Islamic world. This was the beginning of Post-Islamism.

Post-Islamism neither suggests an abandonment of Islamic principles nor a total discard of the Islamic political identity. Rather, it is a transcendent consciousness articulating the complimentary connection between Islamic practices and modern political expectations. Post-Islamists view the Islamic state as hypothetically insular and rigid, one that is neither pragmatic nor competent in advancing the cause of Muslims in a globalizing and multicultural world. Instead, they envision an alternative Islamic polity in the form of an Islam-grounded secular democracy. Scholar Asef Bayat (2013) states this clearly when he noted that Post-Islamism involves "emphasizing rights instead of duties...historicity rather than fixed scriptures, and the future instead of the past. It wants to marry...Islam with democracy and modernity, to achieve what some have termed alternative modernity" (p.8). Post-Islamists generally argue that since the concepts of equality, freedom, and social justice bridge both Islam and modern democracy, there should be no misgiving about whether Islam and modern secularism can be mutually accommodating.

Bayat (2013, p.10) further states that Post-Islamism is more than just political awareness or condition, it is also a project. Many who subscribe to this philosophy are experimenting in the same paths of early European socialist and Christian democratic parties who have operated successfully within the secular system. In Turkey, the transition from Islamism to Post-Islamism can be evidenced through the branching of certain factions of the Islamist Milli Gorus organization. The largest of these has been the Justice and Development (AK) Party (Dagi, 2005). In Tunisia, the country's once-Islamist Nahda party is now the largest in parliament. The party has discarded its Islamist tag and officially detached itself from its religious identity. Calling themselves "Muslim Democrats," its founder Rachid Ghannouchi remarked: "Nahda has evolved from defending identity to ensuring the democratic transition, and today moves on to focus on the economic transition" (Saleh, 2016).

More surprisingly, Post-Islamism has also resonated in Lebanon with the once-militant Shia Islamist group Hezbollah. In its 2009 party manifesto, there was neither a mention of an Islamic state nor the political ideology of wilayat al faqih, which articulates the supremacy of Shia jurisprudence over other forms of law (Alaga, 2011). Part of the increasingly moderate stand by the party can be attributed to the influence of the late Ayatollah Muhammad Hussein Fadlallah, who was described as a "realist" Islamist. Emphasizing that Lebanon was a multi-confessional country, he advocated for an Islam-based civil state that reconciles religious values with democratic norms (Nasr, 2006, pp. 180-182). While it is still 
early to forecast any major success of Hezbollah's Post-Islamist projects, the party seems to be charting a new course in political Islam in Lebanon, one that is substantially different from the Islamism that had preoccupied its predecessors.

The development of political Islam in Indonesia seems to be heading in a similar direction. To understand and explain its movement toward Post-Islamist politics, this essay uses a comparative-historical approach to examine the factorial exchanges between world-historical events and the country's internal socio-political experiences. This will be discussed in the subsequent sections.

\section{Colonial Roots of Political Islam in Indonesia}

Indonesia is currently the largest Muslim country in the world in terms of population, and the fifth most populous overall. Islam reached the Malay Archipelago through trade in the 11th century, giving rise to clusters of medieval Muslim empires such as Malacca, Riau, and Mataram. Large parts of present Indonesia were later colonized by the Dutch, first through the Dutch East India Company (VOC) and then later, directly from the Netherlands. Under Dutch rule, the majority of Muslim-Indonesians were marginalized in every aspect of social, political, and economic life.

Early Islamic movements were thus driven by a sense of Pan-Islamic consciousness to unite Muslims, whose economic power was also being eroded by the encroachment of foreign (mainly ethnic Chinese) competitors (Hannigan, 2015, pp. 167-168). The first of such organizations was Sarekat Dagang Islam (Muslim Traders Union), established in 1911. Later, pilgrims returning from the Haj in Mecca founded a reformist movement, the Muhammadiyah. Its main goal was to address the social-economic enervation of Muslims through modern education. In response, Muslim traditionalists consolidated their own organizational identity in 1926 by forming the Nahdlatul Ulama (NU). These groups would later play an integral role in the social and political development of Islam in the country's post-independence years.

\section{Development of Political Islam in Post-Colonial Indonesia}

Indonesia proclaimed its independence in 1945 and went on to fight an atrocious revolutionary war against both the Dutch and British. Having participated gallantly in the revolution, Indonesia's main political groups-the nationalists, Islamists, and communists-were rewarded with extensive representation in the country's People's Representative Council (Dewan Perwakilan Rakyat or DPR). The relationship between the three factions during the early years of independence was tenuous, however, especially since none was able to assume supremacy over the others.

The state was particularly concerned with Islamist groups and their aspirations for an Islamic state. Official propaganda regularly reminded Indonesians of the pre-eminence of the secular system embedded in the Pancasila (philosophical foundation of the Indonesian state) and the national constitution (Intan, 2006). ${ }^{1}$ Thus militant Islamists were often harshly dealt with. Among them was the Darul Islam. During colonial rule, the western Java region had been a stronghold of this group, whose charismatic leader Kartosuwiryo had proclaimed an "Islamic State of Indonesia." After the Dutch were permanently ousted, Darul Islam sustained its influence and even expanded through affiliates in Aceh (in northern Sumatra) and Southern Sulawesi. It was not until martial law was imposed in the late 1950s and its leaders executed in 1962 that Indonesian forces were able to gain full control of the region.

For the more conventional Islamist groups, the social-political process became the preferred avenue of struggle. The largest reformist party Masyumi did relatively well in Indonesia's first elections in 1955, coming in second behind the nationalists with 21 percent of the total votes. It had a following of more than 10 million in constituencies located mainly in the urban areas and the outer islands (Madinier, 2015, p. 364). Masyumi's Islamist influence, however, was checked by Nahdlatul Ulama (NU). The NU, a leading Islamic charitable and educational organization, today commands the support of 40 million followers (nadhiyyin) residing mostly in the poor rural heartlands of Java. It became a political party in the 1955 elections specifically to stem the spread of Masyumi's reformist influence, which had already reached substantial levels by the mid-1950s (Hannigan, 2015, p. 212). The NU performed admirably with 18 percent of the total votes, just behind Masyumi. Being traditionalists, the NU tend to side with the status quo. The ability of its members to eventually penetrate important state bureaucracies and councils ensured its continual presence in national policy-making (Fealy \& Bush, 2014). Wahid Hasyim, the son of NU's founder, was Indonesia's first Minister of Religious Affairs. Today it has returned to being a a non-political body.

Combined, all Islamic parties who participated in the inaugural elections won 43 percent of the casted votes and took 110 of the DPR seats, compared to 57 held by the nationalists from the Indonesian National Party (PNI). Not included in this was Indonesia's largest reformist group, Muhammadiyah, who has never relinquished its non-political stance. Despite other Islamic groups' experimentation in politics, the organization has remained devoted to its religious and educational activities through $d a^{\prime}$ wah (invitation). Today, it has a membership of 30 million. As the most successful

\footnotetext{
1 The five principles of the Pancasila are belief in God; just and civilized society; unity; democracy; and social justice.
} 
missionary group in the country, many of its pioneer educational institutions have become full-fledged universities numbering in the dozens, with their graduates becoming part of Indonesia's rising middle class.

Throughout the decades after independence, the mutual rivalry among Islamic groups made it difficult for a cohesive front to emerge against the nationalists, who were backed by the military. The extent of power and direction of Islamist groups were also very much swayed by the impact of the cold war on Indonesian politics. In 1957, Indonesia's first president, Sukarno, declared that western-style democracy could never function in Indonesia. He followed this with the clamping down of the country's democratic institutions and the implementation of an alternative system called "guided democracy." Among other things, this new system granted Sukarno paramount power, allowing him to play off the nationalists, communists, and Islamists against each other. Serious challenge to Sukarno's autocratic rule came from two violent revolts between 1957 and 1961. One was led by a coalition of civil and military leaders in Sulawesi under the Pemesta (Universal Struggle Charter) rebellion. The other, in Sumatra, was commanded by disaffected military officers who proclaimed their own Revolutionary Government of the Republic of Indonesia (PRRI). Both were successfully suppressed. A casualty from this however, was Masyumi, which was slapped with a permanent ban from politics for allegedly endorsing the rebellions. This served a firm lesson for other Islamists who may have sympathized with or had any ambition of conducting their own anti-systemic struggle against the state. The state's tight grip on the country's political life would consequently result in reformists and traditionalists persistently battling over positions within the state bureaucracies (Abbas, 2015).

Abroad, Sukarno broadened his alliances. He began cozying up to the Soviet Union, and later, China, especially after it was discovered that the US had a hand in abetting the PRRI rebellion. At home, Sukarno presented Indonesian communists with greater freedom, which boosted the morale of its largest party, the Communist Party of Indonesia (PKI). The PKI took advantage of this unprecedented latitude to carry out many of its projects, which included the collectivization of farms, empowerment of workers' unions, and expansion in recruitment. By the mid-1960s, the party was almost 3 million strong. This inevitably alarmed all Islamic groups, who had had a history of enmity with the communists ever since the turbulent Madiun Affair of 1948. The violence surrounding this incident was triggered by a communist challenge against the revolutionary forces in the central Javanese city of Madiun, which nearly undermined the greater struggle for Indonesian independence (Hannigan, 2015, p. 206).

Sukarno's close relation with the PKI was meant to offset the potential challenges from the various political quarters, especially Islamists, but this strategy soon imploded. In 1965, an attempted coup-purportedly engineered by the communists - resulted in the assassination of six of Indonesia's top generals. The backlash was catastrophic. What entailed was an orgy of torture and murder of nearly half a million suspected communists, committed mostly by vigilante groups. Some sectors within the NU, along with several Catholic groups, were also incentivized to join (Roosa, 2016, p.203). The obliteration of the PKI was accompanied by the forcible resignation of the hugely popular Sukarno. In his place, a young general named Suharto ascended to the presidency.

A new era in politics had now begun in Indonesia, aptly named the New Order. Fully-backed by the west, this new system established a dual function (dwi fungsi) for the armed forces as both a military and administrative institution. After the communist purge, Suharto's military-backed regime turned to suppressing Islamic groups, especially Islamists. By the early 1970s, Islamists had an enormous support base, providing the most observable challenge to the state. Several Islamist leaders were also among the most vocal detractors of the state; they were stridently critical of the intrusive role of the military as well as the prevalent corruption among the leadership. In response, the state embarked upon a structural surveillance of all Islamic political organizations. It formally began in 1973 with the forcible merging of all Islamic-based parties under the United Development Party (PPP) coalition. Although this eventually gave the state comprehensive control of Islamist movements, the PPP's surge in the 1977 elections did little to allay the state's uneasiness about the perceived peril posed by this faction. This concern would be further heightened in 1979 by the Iranian Revolution, which created a new wave of confidence among Islamists worldwide in the possibility of an Islamic state.

Subsequently, the state began to take drastic steps. Aside from rigid policing, this also involved publicly presenting Islamists as an unrelenting menace to national security (Hadiz, 2016, pp.103-110). In a seemingly despairing move, the national deputy head of intelligence Ali Murtopo was even known to have groomed a militant group called the "Jihad Command," whose "perpetration" in a series of terrorist acts would conveniently provide justification for the state's blanket crackdown on all Islamic organizations (Vickers, 2013, p.183). ${ }^{2}$ The Indonesian state also took a page from their former Dutch colonizers by utilizing the media and schools to carry out deleterious campaigns against local

\footnotetext{
2 Acts of terrorism included the hijacking of an Indonesian airliner, bombing of several banks, attacks on police stations, and vandalizing of the ancient monument Borobudur. See Adrian Vickers, A History of Modern Indonesia (New York: Cambridge University Press, 2013), p. 183.
} 
Islamic groups. It even built the Museum of Eternal Vigilance in Jakarta to specifically remind Indonesians of the "atrocities" committed by the Darul Islam during its revolts (Formichi, 2012, p.187).

Additionally, the Suharto regime also worked toward sidelining members from Islamic groups. This was partly achieved through the economic patronage of ethnic Chinese corporate elites and the appointments of Christians in high administrative offices. More significantly, the state formed a pro-government electoral body known as the Joint Secretariat of Functional Groups (Sekretariat Bersama Golongan Karya or Golkar). Golkar would become Suharto's primary political machinery, comprising various representatives from the civil services, trade unions, women's organizations, and the military to name a few, who would endorse the state on numerous policy matters. Though technically not a political party, Golkar participated in elections to eventually become the majority force in the New Order Parliament throughout the 1970s and 1980s (Vickers, 2013).

At the same time however, Islam was too important and too large an entity to alienate. Gradually, the state began to cultivate and promote its own circle of Muslim leaders as a way to expand Muslim support for the New Order. In 1991 a state-sanctioned think tank, the Association of Muslim Intellectuals (ICMI), was established as a forum to address the various social economic problems affecting poor Muslims. The larger aim was for the association to become a platform for forging closer links with the Muslim masses. Gradually, several trusted ICMI members were recruited into Golkar (Bertrand, 2004, p.107). This particularly attracted individual reformists who lacked a political base. Among its more well-known members was the former Muhammadiyah Chair, Amien Rais, who was to be a leading figure in the call for political reform. Although the cooptation of ICMI members into Golkar and other state organizations was aimed at implanting Islam under the authority of state bureaucracies, it also inadvertently facilitated an emerging Islamist presence inside the state machinery. At the very least, it endowed members from a variety of Islamic groups with the critical knowledge and experience needed in high-level administration.

By the 1980s however, the state's control over Islamist groups had been well-entrenched. Criticism and denunciation of government policies was eventually prohibited. ${ }^{3}$ This was manifested in a legislation passed in 1985 to affirm the Pancasila as the sole foundation (asas tunggal) of Indonesia's national philosophy; any individual or mass organization that publicly expressed otherwise was labeled seditious (Van Langenberg, 1990, p. 123). To the state's advantage, the new constriction in freedom occurred within the backdrop of the 1990s economic boom that provided tremendous wealth for the state and legitimacy for its policies (Martin, 1997, p. 125). Despite widespread knowledge of the deep-seated corruption surrounding Suharto and his family, the state was nevertheless accredited with the country's rapid economic growth from 1990 to $1996 .{ }^{4}$

While Indonesia's industrial development served to consolidate Suharto's supreme authority, the Asian financial crisis that followed in 1997 ultimately undermined it. The near collapse of the economy and the rapid social deterioration that ensued were widely blamed on the incompetency, corruption, and cronyism of state leaders. At the same time, the global tsunami of democratization following the 1989 fall of the Berlin Wall was now reaching Indonesia. The state had to consequently contend with mounting public pressures for democracy coming from a conglomeration of groups and organizations across nearly every level of society under the reformasi (political reform) banner. Their demands included that Suharto resign from office and that the military end its involvement in politics. The timing could not have been more apposite. The conclusion of the cold war now meant that the US no longer needed a staunchly anti-communist ally in Indonesia. Abandoned by the West, Suharto was now helpless in preventing his removal from power in 1998 (Budiarjo, 2000, p.57). A new era in democracy had arrived.

\section{Rise of Post-Islamism in the New Indonesia}

The first few years of post-Suharto democracy had been tumultuous. Darul Islam's secessionist legacy, for instance, resurged and intensified in northern Sumatra in the shape of the Gerakan Aceh Merdeka (Free Aceh Movement). In 2005, this group and the Indonesian state successfully negotiated an end to its decades-long separatist war. In return for peace, the Acehnese were given special autonomy to administer their province under Islamic laws. Elsewhere, the vacuum left behind by an all-powerful dictatorship was also exploited by an emboldened breed of radical groups such as the Hizbur Tahrir, Majlis Muhajideen Indonesia, and Jemaah Islamiyah. Although disparate in their ideological postures, these groups shared the conviction that since the Sharia was directly handed down from God, its supremacy and authority were non-negotiable. Muslims who questioned it were disavowed as apostates. Bent on transforming Indonesia into an Islamic state, isolated but deadly terrorist attacks were carried out in Bali in 2002 and Jakarta in 2003 and 2004.

\footnotetext{
${ }^{3}$ An example of this can be captured in the 1984 Tanjung Priok riots in Jakarta. The incident began when a mosque displayed banners criticizing the state, which quickly escalated into protests that were brutally suppressed by the military, resulting in hundreds of deaths.

${ }^{4}$ Suharto was also given the endearing nickname of "Bapa Permodenan Indonesia" (Father of Modern Indonesia).
} 
These militants however, represented a small minority in both membership and support. Their violent campaigns were also expediently crushed by the police. Other than in Aceh, the gradual democratization of Indonesia witnessed an accompanying shift among a number of the country's Islamist parties and organizations toward greater liberalization. Many began re-navigating their political philosophy by aligning fundamental Islamic values with secular democratic norms. The Prosperous Justice Party (PKS) is a prime example. In the 1999 elections, the PKS (known then as the Justice Party or PK) campaigned on an exclusively Islamist platform. In highlighting the virtues of the Islamic state, it called into question the credibility of the modern Indonesian state in fulfilling Muslim needs and aspirations. This approach failed. Indonesians who had recently been emancipated from the grasp of a dictatorship found the prohibitive nature of Islamism unattractive, especially so for the growing number of people in the middle class. It wasn't surprising then that the party garnered only 1.4 percent of overall votes in that election.

The PKS has since changed its political vision. While maintaining Islam as its overarching framework, the PKS has re-oriented its goals toward adapting to the demands of a democratizing Indonesia (Elson, 2010). More significantly, the party expanded its political goals away from the thematic confines of the Islamic state. Instead, its focus has shifted toward a moral-universal struggle against what it believes are widespread and commonly-agreed problems besetting the country - the rampant corruption, the omnipresent disparities, and the prevalent disenfranchisement of marginal groups. Its official objectives now include: reforming the country's political, administrative, and judicial systems toward greater democracy; addressing poverty and unemployment through improved income equality and sustainable development; and establishing a just and quality education system accessible to all Indonesians (Majelis Pertimbangan Pusat PKS, 2008, pp.106-136).

Hence, the PKS has rebranded itself with a new identity as an Islam-based party in pursuit of social reform through greater democracy. In generating electoral support, the PKS has forged collaborative networks with secular parties and organizations who share similar social justice goals. Anis Matta, the Secretary-General of PKS, reiterated that "in Islam, cooperation is a good thing" (Bubalo, Fealy, \& Mason, 2008, p. 48). By doing this, the PKS has also successfully projected its image as a pluralistic movement for justice serving all Indonesians. This new and moderate approach greatly contributed to the party's improved performance in the 2009 elections (Hamayotsu, 2011).

Critics have claimed that the PKS had abandoned its Islamist principles for political mileage; others questioned whether it is genuinely espousing secular democracy and not merely using the electoral process to further its Islamist aims. To this, the PKS responded by stating that it truly believes modern democracy to be compatible with the major principles of Islam (Hasan, 2013). The secular concepts of rights, inclusion, and peaceful co-existence, as embodied in the Indonesian constitution, it asserts, are not unfamiliar in Islam. In fact, they formed the core principles of the Medina Charter under which Islam's first state was governed by the Prophet Muhammad more than a thousand years ago. Echoing the philosophical reasoning of well-known Islamic scholar Yusuf Qardawi, the PKS declared that submitting to God's divine sovereignty does not preclude Muslims from the right to administer their societies with relevance to time and place (Hasan, 2013, pp. 172-173). To the PKS, the time is the age of global democratization, and the place is a culturally diverse Indonesia.

The PKS was not alone in experiencing electoral success. Although secular parties such as the Indonesian Democratic Party (PDI), Golkar, and the Great Indonesia Movement Party (Gerindra) received the larger victories in the 2014 elections, newer parties who carried with them a Post-Islamist message also did relatively well. The National Awakening Party (PKB) - which drew much of its backing from the NU-and the National Mandate Party (PAN) - which received large support from Muhammadiyah members - saw their electoral support rise to about 32 percent of the total votes. According to analyst Greg Fealy, "None of the Islamic parties that passed the 3.5 percent parliamentary threshold campaigned using Islamic concepts or doctrines" (quoted in Coca, 2014). Rather, these parties ran on a consistently universalistic and secular message, appealing to a national audience who were religiously inclined but who prioritized sound economic policies and clean governance. On the other hand, parties which remained invariably Islamists such as the PPP and Crescent Star Party (PBB) performed miserably, with the latter capturing only 1 per cent of total votes.

There are several interactive factors that explain why Islamist organizations and parties in Indonesia are moving toward Post-Islamist trends. First and foremost is the nature of Islam's historical development in Indonesia. Over the centuries, syncretic fusions with a diversity of indigenous traditions have produced a version of Islam that is unique to the Malay world, one that is intrinsically different from that in the Middle-East and more amenable and adaptive to political economic changes. This has given birth to large Muslim organizations which cater to the various needs and facets of "Indonesian Islam." By largely maintaining a non-political role, these organizations have concentrated on various charitable and educational works, which have had immense influences on the welfare and social outlook of Muslims in Indonesia. 
Importantly, these organizations have successfully tempered the rise of radical strains of Islam in Indonesia. The NU, for example, was founded as a mission to preserve Indonesian Islam. This requires reconciling religious practices with various aspects of local cultural life. One way of doing this was to encourage its highly-revered scholars the flexibility to issue fatwas (religious rulings) through ijtihad, a methodology in independent reasoning used to interpret, clarify, and respond to particular problems not specifically mentioned in either the Quran or hadith (sayings and examples of the Prophet). The origin of ijtihad can be traced to several verses in the Quran that allude to interpretive reasoning as vital for religious scholarship and legal decision-making (The Quran, At-Tawbah 9.12; As-Shuraa, 42.38). This practice had been widely used during the vibrant years of the Abbasid caliphate from the $8^{\text {th }}$ to $10^{\text {th }}$ centuries, but did not surface again until the late $19^{\text {th }}$ century when several Islamic scholars deemed it necessary to resolve many of the embryonic problems faced by Muslims during European colonization.

Over the years, the NU has expanded its use of ijtihad in two ways. One has been its scope of focus to include social issues such as family planning, organ donation, and consumerism. The other has been in the collective nature of decision-making, in which it has expanded the pool of participants to include "secular" experts such as psychologists, engineers, and medical practitioners. Hosen (2004) concludes these efforts to be "evidence that the Indonesian ulama are less rigid in their interpretation of Islamic positioning than is the case elsewhere in the world" (p. 25). This is especially so since their fatwas have been seen to conform to the needs of the current social conditions, with outdated ones often replaced by newer and temporally suitable ones.

Outside of religious work, the NU has shown seriousness in furthering the country's democratization efforts, especially in promoting civility, religious tolerance, and social justice. An example of this effort has been the formation of Jaringan Gusdurian, a network that seeks to foster inter-cultural and inter-faith coalitions across the country and throughout the world. Jaringan's national coordinator, Alissa Wahid, said this network represents the identity of Islam in Indonesia: "Indonesia exists due to its diversity, meaning that tolerance and pluralism have become the essence of our nation" (quoted in Sudarman, 2014). Its main works focus on addressing and solving problems relating to poverty, racism, inequality, and social injustice. This, it believes, is especially vital in preventing extremism and radicalism among the disenfranchised.

The NU has also embarked on projects that accentuate the compatibility between Islamic values and progressive democratic principles. An example has been the formation in 2000 of Syarikat (Indonesian acronym for Santri Society for People's Advocacy). Building upon the Islamic moral concepts of truth (mafhum alhaqq), repentance (taubat), and reconciliation (istigfar), this organization aimed at re-examining events surrounding the 1965 anti-communist purge, in which several members of the NU were involved. One of Syarikat's main goals is to challenge the ancien regime's historical narrative of the foiled coup, which had laid blame solely on the PKI. Recent historiographies have increasingly disputed the role of the communists in the 1965 assassinations. Instead, they point to members of the Indonesian military, with the support of the US, Britain, and Australia, who all feared communism's domino-effect across Southeast Asia (Hallinan, 2012; Hilton, 2001). Another goal is to provide the NU with organizational legitimacy through repentance and forgiveness from victims who have survived and the families of those who have perished (McGregor, 2009). Here, the role of the young has been critical. Despite heavy resistance from various conservative groups, they have remained dedicated to undertaking investigative researches into the tragedy as well as providing assistances to victims and their families. This is not surprising as Hamayotsu (2011) explains: "young Muslims (in Indonesia) are a post-authoritarian generation who are hungry for change to build a better political and social system under a new democratic regime" (p.232).

Meanwhile, Muhammadiyah, which had stringently advocated for a return to more rudimentary practices of Islam, has since focused on re-configuring its brand of Islam to acclimate Muslims to important aspects of modern life. Its philosophical direction has increasingly gravitated toward re-defining its institutional relevance in the new Indonesian democracy. On whether Islam and democracy could be complementary in Indonesia, Din Syamsuddin (2008), Chair of Muhammadiyah remarked "I believe democracy is the best system, but it has to be established within the proper context. The Indonesian context is to resolve differences through compromise" (p.3).

According to Hefner (2000, p.74-76), the pursuit of a civil and democratic Islam among many prominent scholars and thinkers had already been in place well before the demise of the Suharto government. Former Muhammadiyah leader Amien Rais, who is well-respected among both Muslims and non-Muslims, had long been a proponent of merging Islamic principles with secular-universalistic values (Mietzner, 2009, p. 161). The comprehensive and secular flavor of his message enabled him to establish working relations with various civil organizations, university students, and other religious groups during his leading role in the reformasi movement. This certainly helped with the mobilization of cumulative grassroots protests that eventually ousted Suharto from the presidency, paving the way for a new democratic beginning in Indonesian politics. 
Increasingly, a host of Islamist groups and organizations in Indonesia have acknowledged the new and democratized process as the most appropriate vehicle for achieving their political goals. The ascendancy of former NU Chair Abdurrahman Wahid to Indonesia's fourth presidency in 1999 had offered substantial assurance to various Islamic groups that the country's nascent democracy and electoral process provided a legitimate and systematic means to political power. This prompted many Islamists to declare Indonesia to be in a state of peace or darul aman. With the state no longer a serious obstacle to attaining political goals, many have begun to acknowledge the irrelevance of the struggle for an Islamic state as the sole platform for advancing Muslim interests; others have publicly denounced as un-Islamic, the use of any form of force or extremism in the pursuit of political goals (Hasan, 2013, p. 164).

Another factor explaining this observable transition toward Post-Islamism in Indonesia lies in the emergence of an influential middle class celebrative of the new democracy. As a by-product of the country's industrializing economy, this newly-educated class seems to favor balancing religious obligations with career aspirations and opportunities which an Islamic state may not fully ensure. According to Machmudi (2008), the new middle class is unlike the old santri (religious) middle class in that it is not fixated on specific religious teachings. Having enjoyed the fruits of an economically vibrant and democratizing Indonesia, this class has taken on a different dimension in religiosity; it is no longer characterized by a strict interpretation of or total abidance to religious scriptures in every aspect of social and political life. Rather, it has been marked by their ability to develop a union between both traditionalist and reformist forms of Islam that is adaptable to the demands of an emerging democracy (Hasan, 2013, p.173). This includes a sense of civic morality emanating from the fusion of Islamic religious ideals with a practical lifestyle centered on individual rights and liberties. Thus while members of this class may seem outwardly religious judging by their captivation in "things Islamic" found in fashion, literature, and rituals, their rising interests in career-related goals and opportunities have also made them more open and receptive to changes in religious outlook (Anwar, 1995, pp. 126-127). Greg Fealy (2008, pp.15-39) calls this form of religiosity "aspirational pietism," which in the long run could serve to widen the expressive identities of Islam in Indonesia.

In this respect, the future of Post-Islamism in Indonesia may greatly rest on members of the younger generation and the middle class, especially when the highly-talented are able to make their way into the various branches of civil organizations, government, and businesses with this new sense of openness and tolerance (Hamayotsu, 2011, p. 242). It is also dependent on the scope of success of main Islamic groups such as the NU and Muhammadiyah in sustaining the plurality of Indonesian Islam. Finally, a more extensive transition to Post-Islamism also hinges upon the continuing work by the state, civil society groups, and religious scholars to emphasize moderate middle grounds between religious and secular life.

\section{Conclusion: Future of Post-Islamism in Indonesia}

It is relatively early to anticipate the extent to which Post-Islamism will be mainstreamed into Indonesian politics. There is however, an apparent desire on the part of the current state to foster an Islam that is flexible, inclusive, and compatible with the diverse socio-historical characteristics of the country's population. In a Jakarta Post article, Kamaruddin Amin (2016), Director of Religious Education in the Ministry of Religious Affairs expressed his confidence that Indonesia could progress toward a model Islamic society. He pointed to the primary advantage Indonesia possesses over other predominantly Muslim countries in the immensity of its secular infrastructure, which has been ideologically protected and constitutionally expressed through its highly-venerated Pancasila. The country's post-Suharto democratization has since rejuvenated a sense of zeal for the separation between religious life and politics, especially among Muslims who also prioritize other important aspects of personal and social life such as occupational achievement, consumerism, and effectual suffrage.

There has also been increased consensual preference among Islamic organizations and scholars for the institutional intersection between Islam and secularism. This is evidenced by numerous large Islamic organizations and political parties who have reconstructed their philosophical identities toward greater moderation, tolerance, and appreciation for secular democracy. Even Islamists who had previously obsessed themselves with the creation of the Islamic state are now moving their philosophical platforms along more pragmatic paths. At the same time, various important sectors in the country seem to have worked collaboratively well in safeguarding Islam from the threat of religious extremism. As Indonesia democratizes, newer generations of Indonesian scholars and activists have unwaveringly subscribed to the narrative that political economic exclusion and social discontentment often leave the excluded vulnerable to radical indoctrination. The activism and missions of main Islamic organizations such as NU and Muhammadiyah have aimed at addressing this problem by alleviating the social, political, and economic plights of marginal groups. As long as the state complements these efforts by structurally creating opportunities for the underprivileged while keeping the flames of democracy alight, all these will continue to provide indicators toward the regularizing of Post-Islamism in Indonesia.

Post-Islamism also requires sustained economic growth. There must be stable and continuous provisions in national 
resources for greater job potentials and the financing of social programs. This is also critical for the sustenance of a burgeoning and educated middle class. These are segments of the citizenry who relish the wide range of freedom and opportunities offered by the country's newly-found democracy, and who would not settle for a system that offered anything less than their right to choose their personal goals and the government of their choice. A rising urban middle class in a growing economy, along with the younger generation constituting 45 percent of the country's population, would also form a formidable bulwark against potential threats arising from radicalization and authoritarianism. The prospects seem bright as Indonesia's economy is the $16^{\text {th }}$ largest in the world, with the country performing at the upper tier of newly industrializing countries. Here, global economic factors play a significant role in determining the extent of Post-Islamism in Indonesia's politics.

It is inarguably obvious that Post-Islamism has been making a strong presence in Indonesia. In this regard, it is only befitting that the country with the largest Muslim population would set an exemplary pace for the development of a modern Islamic democracy, one that acknowledges the importance of religion in the lives of its people while valuing individual rights, liberty, and justice for all its citizens.

\section{References}

Abbas, M. B. (2015). Battling over the Bureaucracy: The 10 October incident and intra-Muslim conflict under Sukarno's guided democracy. Indonesia and the Malay World, 43(126), 207-225. http://dx.doi.org/10.1080/13639811.2015.1029343.

Alaga, J. (2011). Hizbullah's identity construction. Amsterdam University Press.

Amin, K. (2016, May 20). Can Indonesian Islam be a model for the rest of the Muslim world? The Jakarta Post. http://www.thejakartapost.com/news/2016/05/20/can-indonesian-islam-be-a-model-for-the-rest-of-the-muslim-wor ld.html.

Ansari, T. (2009). Destiny disrupted: A history of the world through Islamic eyes. New York: Publicaffairs.

Anwar, M. S. (1995). Pemikiran dan aksi Islam Indonesia: Sebuah kajian politik tentang cendiakawan Muslim Orde Baru. Jakarta: Paramadina.

Bayat, A. (2005). Islamism and social movement theory. Third World Quarterly, 26(6), 891-908. http://dx.doi.org/10.1080/01436590500089240.

Bayat, A. (2013). Post-Islamism at Large. In A. Bayat (Ed.), Post-Islamism: The changing faces of political Islam, 3-34. New York: Oxford University Press.

Bertrand, J. (2014). Nationalism and ethnic conflict in Indonesia. Cambridge, UK: Cambridge University Press.

Bubalo, A., Fealy, G., \& Mason, W. (2008). Zealous democrats: Islamism and democracy in Egypt, Indonesia and Turkey. Sydney: Lowy Institute for International Policy.

Budiarjo, C. (2000). Legacy of the Suharto dictatorship. In P. Hainsworth \& S. McCloskey (Eds.), The East Timor Question: Struggle for independence from Indonesia , 51-68. London: I.B. Tauris \& Co.

Coca, N. (2014). Is political Islam rising in Indonesia? Al-Jazeera. Retrieved from http://www.aljazeera.com/indepth/features/2014/04/political-islam-rising-indonesia-.html.

Dagi I. (2005). Transformation of Islamic political identity in Turkey: Rethinking the west and westernization. Turkish Studies, 6(1), 21-37. http://dx.doi.org/10.1080/1468384042000339302.

Dagi, I. (2013). Post Islamism a la Turca. In A. Bayat (Ed.), Post-Islamism: The changing faces of political Islam, (pp. 71-108) New York: Oxford University Press.

Dallal, A. (1993). The origins and objectives of Islamic revivalist thought, 1750-1850. Journal of American Oriental Society, 113(3), 341-359. http://dx.doi.org/10.2307/605385

Elson, R. E. (2010). Nationalism, Islam, and the "secular" state in contemporary Indonesia. Australian Journal of International Affairs, 64(3), 328-343. http://dx.doi.org/10.1080/10357711003736493.

Fealy, G. (2008). Expressing Islam: Politics and religious life in Indonesia. Singapore: ISEAS-Yusof Ishak Publishing.

Fealy, G. \& Bush, R. (2014). The political decline of traditional ulama in Indonesia: The state, umma, and Nadhlatul Ulama. Asian Journal of Social Science, 42(1), 539-540. http://dx.doi.org/ 10.1163/15685314-04205004.

Formichi, C. (2012). Islam and the making of a nation: Kartosuwiryo and political Islam in twentieth-century in Indonesia. Leiden, Netherlands: KITLV Press.

Hadiz, V. R. (2016). Islamic populism in Indonesia and the Middle East. Cambridge, UK: Cambridge University Press. 
Hallinan, C. (2012). New York Times continues to conceal US role in 1965 Indonesia coup, FPIP. Retrieved from fpif.org/new_york_times_continues_to_conceal_us_role_in_1965_indonesia_coup/

Hamayotsu, K. (2011). Beyond faith and identity: mobilizing Islamic youth in a democratic Indonesia. The Pacific Review, 24(2), 225-247. Http://dx.doi.org/ 10.1080/09512748.2011.560960

Hannigan, T. (2015). A brief history of Indonesia: Sultans, spices, and tsunamis. Hong Kong: Tuttle.

Hasan, N. (2013). New York: Oxford University Press.Post-Islamist Politics in Indonesia. In A. Bayat (Ed.), Post-Islamism: The changing faces of political Islam, 17-184.

Hefner, R. W. (2000). Civil Islam: Muslims and democratization in Indonesia. Princeton, NJ: Princeton University Press.

Hilton, I. (2001). Our bloody coup in Indonesia, The Guardian. Retrieved from http://www.theguardian.com/world/2001/aug/01/indonesia.comment.

Hosen, N. (2004). Nahdlatul Ulama: Collective Ijtihad. New Zealand Journal of Asian Studies, 6(1), 5-26. Retrieved from http://www.nzasia.org.nz/downloads/NZJAS-June04/6_1_2.pdf.

Intan, B. F. (2006). Public religion and the Pancasila-based state of Indonesia: An ethical and sociological analysis. New York: Peter Lang.

Lapidus, I. (1997). Islamic revival and modernity: The contemporary movements and the historical reading. Journal of Economic and Social History of the Orient, 40(4), 444-460. Http://dx.doi.org/10.1163/1568520972601486.

Machmudi, Y. (2008). The emergence of the new santri in Indonesia. Journal of Indonesian Islam, 2(1), 69-102. Http://dx.doi.org/10.15642/JIIS.2008.2.1.69-102.

Madinier, R. (2015). Islam and politics in Indonesia: The Masyumi party between democracy and integralism. Singapore: NUS Press.

Majelis Pertimbangan Pusat PKS. (2008). Falsafah dasar perjuangan dan platfom kebijakan perjuangan PKS. Jakarta: PKS.

Martin, D. (1997). Political development in Pacific Asia. Malden, MA: Blackwell Publishers.

McGregor, K. E. (2009). Confronting the past in contemporary Indonesia: The anticommunist killings of 1965-66 and the role of the Nahdlatul Ulama. Critical Asian Studies, 4l(2), 195-224. Http://dx.doi.org/10.1080/14672710902809351.

Mietzner, M. (2009). Military politics, Islam and the state in Indonesia: From turbulent transition to democratic consolidation. Singapore: Institute of Southeast Asian Studies.

Nasr, V. (2006). The Shia revival: How conflicts within Islam will shape the future. New York: W.W. Norton.

Roosa, J. (2006). Pretext for murder: The September 30 Movement and Suharto's coup d'etat in Indonesia. Madison, WI: University of Wisconsin Press.

Roy, O. (1998). The failure of political Islam. Cambridge, MA: Harvard University Press.

Saleh, H. (2016). Tunisia's Mahda Party ditches Islamic tag, The Financial Times. Retrieved from http://www.ft.com/cms/s/0/966407b8-2033-11e6-aa98 db1e01fabc0c.html.

Sudarman, S. (2014, January 7). Alissa Wahid: Realizing Gus Dur's dream, The Jakarta Post. Retrieved from http://www.thejakartapost.com/news/2014/01/07/alissa-wahid-realizing-gus-dur-s-dream.html.

Syamsuddin, D. (2008). The role of Islam in developing democracy in Indonesia, USINDO Brief. Retrieved from http://www.usindo.org/wp-content/uploads/2011/04/Syamsuddin-7-31-2008.pdf.

Tajuddin, A. (2012). Malaysia in the world economy (1824-2011): Capitalism, ethnic divisions, and 'managed' democracy. Landham, MD: Lexington Books.

Van Langenberg, M. (1990). The New Order state: Language, ideology, hegemony. In A. Budiman (Ed.), State and civil society in Indonesia. Clayton, Australia: Monash University Press.

Vickers, A. (2013). A history of modern Indonesia. New York: Cambridge University Press.

\section{(cc) BY}

This work is licensed under a Creative Commons Attribution 3.0 License. 